\title{
GAMBARAN STATUS KARIES GIGI ANAK USIA 11-12 TAHUN PADA KELUARGA PEMEGANG JAMKESMAS DI KELURAHAN TUMATANGTANG I KECAMATAN TOMOHON SELATAN
}

\author{
${ }^{1}$ Hansen Ch. Wala \\ ${ }^{2}$ Dinar A. Wicaksono \\ ${ }^{2}$ Elita Tambunan
}

\author{
${ }^{1}$ Kandidat Skripsi Program Studi Kedokteran Gigi Fakultas Kedokteran \\ Universitas Sam Ratulangi Manado \\ ${ }^{2}$ Program Studi Kedokteran Gigi Fakultas Kedokteran Universitas Sam Ratulangi Manado \\ Email: backburnerzz@gmail.com
}

\begin{abstract}
Dental caries is one of the gum diseases which is commonly found in the community (adults and children). The infection process is progressive and accumulated on dental hard tissues characterized by tissue damage which begins from the tooth surface and extends into the pulp. This study aimed to describe the caries status in children aged 11 to 12 years old that belonged to the members of Jamkesmas in Tumatangtang 1 village, Tomohon Selatan. As subjects, there were 54 childrens aged 11 to 12 years old obtained by using total sampling method. This was a descriptive observational study. Measurement of dental caries status was conducted by using an index score of caries. Caries index is a number that indicates the number of dental caries in a person or group of people. The measurement includes the number of decayed teeth (Decay), number of extracted teeth due to caries (Missing) and the number of patched teeth (Filling). DMF - T Index is the simplest and most commonly used in epidemiological surveys of dental caries. The results showed that from the DMF - T index of all samples, the total index D (Decay) 159, M (Missing) 45, and F (Filling) 0. Based on WHO criteria, the average 3.8 belonged to the category of fair caries status. The average of DMF-T index of boys was categorized as fair caries status, meanwhile of girls was categorized as high caries status. Conclusion: Caries status of children aged 11-12 years old that belonged to the members of Jamkesmas in Tumatangtang 1 village, Tomohon Selatan was categorized as fair status.
\end{abstract}

Keywords: caries status, children, DMF-T index

\begin{abstract}
Abstrak: Karies gigi merupakan penyakit gigi dan mulut yang paling banyak ditemukan di masyarakat baik dewasa maupun anak. Infeksi yang terjadi bersifat progresif dan terakumulasi pada jaringan keras gigi yang ditandai kerusakan jaringan, dimulai dari permukaan gigi hingga meluas ke arah pulpa. Penelitian ini bertujuan untuk mengetahui gambaran status karies gigi anak berusia 11-12 tahun pada keluarga pemegang Jamkesmas di kelurahan Tumatangtang I kecamatanTomohon Selatan. Subjek penelitian sebanyak 54 anak yang diperoleh dengan metode total sampling. Penelitian ini bersifat deskriptif observasional. Pengukuran status karies gigi dari 54 anak ini dilakukan dengan menggunakan skor indeks karies yaitu angka yang menunjukkan jumlah gigi karies seseorang atau sekelompok orang. Pengukurannya meliputi jumlah gigi yang rusak (Decay), jumlah gigi yang telah dicabut karena karies (Missing), dan jumlah gigi yang ditambal (Filling). Indeks DMF-T merupakan indeks yang paling sederhana dan paling umum digunakan dalam survei epidemiologi karies gigi. Hasil penelitian memperlihatkan dari pemeriksaan DMF-T pada 54 anak didapatkan total indeks D (Decay) berjumlah 159, M (Missing) berjumlah 45, dan F (Filling) tidak ada, dengan indeks DMF-T rata-rata 3,8 (kategori
\end{abstract}


status karies sedang berdasarkan kriteria WHO). Indeks DMF-T rata-rata pada anak laki-laki tergolong kategori status karies sedang, sedangkan pada anak perempuan tergolong kategori status karies tinggi. Simpulan: Status karies anak umur 11-12 tahun pada keluarga pemegang Jamkesmas di Kelurahan Tumatangtang 1 Kecamatan Tomohon Selatan berada pada kategori status karies sedang.

Kata kunci: status karies, anak, indeks DMF-T

Kesehatan merupakan suatu faktor yang amat sangat penting dalam kelangsungan hidup manusia, begitu juga dengan kesehatan gigi dan mulut. Kesehatan gigi dan mulut secara tidak langsung menjadi bagian penting dan tidak dapat dipisahkan dari kesehatan tubuh secara umum sehingga merupakan investasi seumur hidup. Penyakit gigi dan mulut yang paling banyak ditemukan di masyarakat luas yaitu karies gigi, karies tidak hanya terjadi pada orang dewasa tetapi dapat pula terjadi pada anak. ${ }^{1}$

Hasil Riset Kesehatan Dasar (Riskesdas) Nasional tahun 2007 melaporkan prevalensi karies di Indonesia mencapai 72,1\%dan skor DMF-T mencapai 4,8. Survey Kesehatan Rumah Tangga (SKRT) tahun 2009 menunjukkan bahwa penduduk Indonesia yang menderita karies gigi sebesar 73\%. Menurut data Kementrian Kesehatan Republik Indonesia (Kemenkes RI) tahun 2009, sebanyak 89\% anak Indonesia di bawah 12 tahun menderita karies gigi. ${ }^{2,3}$

Karies gigi ialah penyakit infeksi yang bersifat progresif serta akumulatif pada jaringan keras gigi yang ditandai dengan kerusakan jaringan, dimulai dari permukaan gigi (pit, fisur, dan daerah interproksimal) hingga meluas ke arah pulpa. Faktor utama penyebab karies yaitu host, mikroorganisme, substrat dan ditambah faktor waktu. ${ }^{1}$ Selain itu, faktor resiko yang memengaruhi keparahan karies antara lain pengalaman karies, sosial ekonomi, usia, jenis kelamin, pendidikan, geografis, dan perilaku terhadap kesehatan gigi. ${ }^{1}$ Dari faktor-faktor tersebut semua orang baik anak-anak maupun orang dewasa rentan terkena karies dan tingkat keparahannya di masing-masing daerah dapat berbeda-beda.

Kebiasaan anak mengonsumsi makanan kariogenik seperti coklat, permen, kue-kue manis, dan sebagainya membuat anak-anak sangat rentan terhadap karies gigi. Dampak yang paling umum terjadi bila anak mengalami karies gigi yaitu berkurangnya kehadiran anak di sekolah serta dapat mengganggu konsentrasi belajar, selain itu juga nafsu makan menjadi berkurang sehingga dapat mengakibatkan gangguan pertumbuhan yang nantinya akan mempengaruhi status gizi anak yang berimplikasi pada kualitas sumber daya.

Kemiskinan secara tidak langsung mempengaruhi derajat kesehatan pada seseorang tidak terkecuali kesehatan gigi dan mulut. Permasalahan kemiskinan masih merupakan masalah utama di Indonesia. Badan Pusat Statistik (BPS) mencatat jumlah penduduk miskin pada Maret 2013 mencapai 28,07 juta atau $11,37 \%$ dari total penduduk Indonesia sedangkan tingkat kemiskinan di provinsi Sulawesi Utara pada Maret 2013 mencapai 184,40 ribu jiwa atau $7,88 \%{ }^{4,5}$ Kebijakan pemerintah mengenai kesehatan bagi keluarga miskin terlihat dengan adanya Jaminan Kesehatan Masyarakat (Jamkesmas) yang bertujuan untuk memenuhi hak dasar setiap individu/semua warga negara termasuk masyarakat miskin untuk mendapat pelayanan kesehatan yang layak. Pada intinya, program Jamkesmas ini juga dapat menjaga masyarakat agar tetap sehat, produktif, dan mengurangi resiko pengeluaran kesehatan yang besar supaya pesertanya bisa terbebas dari mata rantai kemiskinan. ${ }^{6,7}$

Berdasarkan uraian di atas, peneliti tertarik untuk mengetahui gambaran status karies gigi anak pada keluarga pemegang kartu Jamkesmas. Penelitian ini dilakukan pada anak umur 11-12 tahun yang merupakan anggota keluarga dari pemegang kartu jamkesmas yang tinggal di Kelurahan Tumatangtang 1 Kecamatan Tomohon Selatan. Peneliti memilih anak umur 11-12 tahun karena menurut WHO, pada usia 12 tahun anak lebih muda diajak berkomunikasi dan diperkirakan semua gigi permanen telah erupsi kecuali gigi molar tiga, serta usia tersebut merupakan kelompok yang mudah dijangkau 
oleh usaha kesehatan gigi sekolah. Oleh karena itu, usia 12 tahun ditetapkan sebagai usia pemantauan global untuk karies. ${ }^{8,9}$ Selain itu, pertimbangan peneliti memilih tempat tersebut karena sekitar 52\% keluarga di kelurahan tersebut merupakan pemegang kartu Jamkesmas dan masih jarangnya penyuluhan maupun sosialisasi dari pihak puskesmas setempat. Diharapkan dari pengambilan sampel ini dapat diketahui gambaran status karies gigi pada anak anggota keluarga Jamkesmas.

\section{BAHAN DAN METODE}

Penelitian ini menggunakan desain penelitian deskriptif observasional, yang menggambarkan status karies anak umur 11-12 tahun pada keluarga pemegang Jamkesmas di kelurahan Tumatangtang 1 kecamatan Tomohon Selatan yang dilakukan pada bulan Januari 2014. Subjek dari penelitian ini adalah anak usia 11-12 tahun yang pengambilan sampelnya dilakukan dengan menggunakan metode total sampling yang berjumlah 54 anak.

Sebelum data dikumpul, didahului dengan survei awal dan permohonan untuk izin penelitian yang diperoleh dari hasil perbincangan dan persetujuan dengan pihak kelurahan Tumatangtang I kecamatan Tomohon Selatan. Sebelum melangsungkan penelitian terhadap subjek, terlebih dahulu membagikan informed concent kepada para orang tua/wali dari anak yang akan diteliti. Setelah informed concent dibagikan dan disetujui oleh para orang tua, kemudian dilakukan pemeriksaan dengan menggunakan alat diagnostik untuk mendapatkan data tentang status karies gigi melalui indeks DMF-T. Status karies adalah suatu kondisi yang menggambarkan pengalaman karies, yang dihitung menggunakan indeks DMF-T. Indeks DMF-T merupakan indeks yang digunakan untuk menunjukan banyaknya subjek yang terkena karies, banyaknya gigi yang membutuhkan perawatan, dan jumlah gigi yang telah dirawat. D (Decay): Apabila jaringan email gigi tetap mengalami dekalsifikasi, terlihat berwarna keputih-putihan atau kecoklatan dengan ujung ekskafator yang terasa menyangkut pada kavitas. Keadaan lain yang termasuk dalam kategori ini yaitu, keadaan karies dengan kavitas besar yang melibatkan dentin, karies mencapai jaringan pulpa baik dengan kondisi vital atau non-vital, karies terhenti, dan karies pada gigi tetap walaupun gigi tersebut terdapat restorasi. M (Missing): Gigi yang hilang atau dicabut karena karies dimasukkan dalam kategori missing, tetapi gigi yang hilang akibat penyakit periodontal, dicabut untuk kebutuhan perawatan ortodonti, dan pencabutan normal selama pergantian gigi geligi tidak dimasukkan dalam kategori ini. F (Filling): Apabila gigi tetap tersebut telah ditumpat atau direstorasi secara tetap maupun sementara maka dimasukkan dalam kategori ini. Apabila gigi yang ditumpat terdapat karies, tidak termasuk kategori ini. DMF-T rata-rata adalah jumlah seluruh nilai DMF-T dibagi dengan jumlah anak yang diperiksa berdasarkan indikator menurut WHO.

Tabel 1. Kategori perhitungan DMF-T menurut WHO

\begin{tabular}{ll}
\hline Kategori & DMF-T \\
\hline Sangat rendah & $0,0-1,1$ \\
Rendah & $1,2-2,6$ \\
Sedang & $2,7-4,4$ \\
Tinggi & $4,5-6,5$ \\
Sangat tinggi & $>6,6$ \\
\hline
\end{tabular}

\section{HASIL PENELITIAN}

Data hasil penelitian menunjukkan indeks DMF-T rata-rata untuk 54 anak dari kelurahan Tumatangtang 1 kecamatan Tomohon Selatan sebesar 3,8 dan berdasarkan kriteria dari WHO, indeks ini berada pada kategori status karies sedang. 

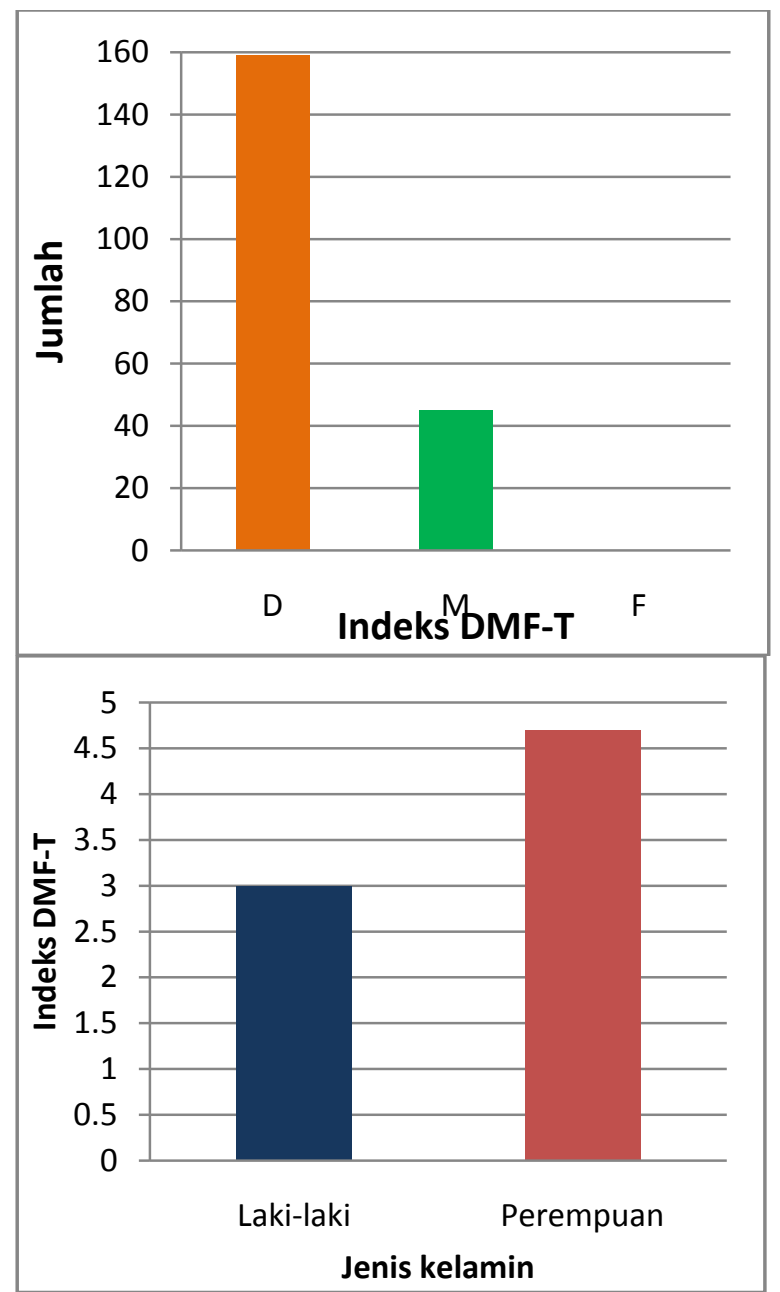

Gambar 2. Diagram distribusi indeks DMF-T berdasarkan jenis kelamin

Data hasil penelitian pada 30 anak laki-laki di Kelurahan Tumatangtang 1 Kecamatan Tomohon Selatan untuk total indeks D (decay) berjumlah 70, M (missing) berjumlah 21 dan F
Gambar 1. Diagram distribusi indeks DMF-T

Dari hasil pemeriksaan DMF-T pada anak usia 11-12 tahun di kelurahan Tumatangtang 1 kecamatan Tomohon Selatan, total indeks D (Decay) berjumlah 159, M (Missing) berjumlah 45, dan F (Filling) tidak ada (Gambar 1).

(filling) tidak ada dan berdasarkan hasil pemeriksaan, 30 anak laki-laki ini memiliki indeks rata-rata DMF-T sebesar 3. Data hasil penelitian pada 24 anak perempuan di Kelurahan Tumatangtang 1 Kecamatan Tomohon Selatan untuk total indeks D (decay) berjumlah 89, M (missing) berjumlah 24 dan F (Filling) tidak ada dan berdasarkan hasil pemeriksaan, 24 anak perempuan ini memiliki indeks rata-rata DMF$\mathrm{T}$ sebesar 4,7. Hasil pemeriksaan indeks ratarata DMF-T pada anak usia 11-12 tahun di Kelurahan Tumatangtang 1 Kecamatan Tomohon Selatan, jelas menunjukkan adanya perbedaan nilai rata-rata indeks DMF-T untuk masing-masing jenis kelamin. Anak laki-laki memiliki rata-rata indeks DMF-T lebih rendah yaitu sebesar 3 dibandingkan dengan anak perempuan yang memiliki rata-rata indeks DMF-T sebesar 4,7 (Gambar 2). 
Tabel 2. Distribusi indeks DMF-T dan status karies berdasarkan jenis kelamin

\begin{tabular}{llllllll}
\hline Indeks & \multicolumn{3}{c}{ Laki - laki } & \multicolumn{3}{c}{ Perempuan } & \multirow{2}{*}{ Status } \\
\cline { 2 - 6 } DMF-T & $\mathbf{n}$ & $\mathbf{\%}$ & $\mathbf{D M F - T}$ & $\mathbf{N}$ & $\mathbf{\%}$ & $\mathbf{D M F - T}$ & karies \\
\hline $0,0-1,1$ & 9 & 17 & 0.4 & 2 & 3.7 & 0.5 & Sangat rendah \\
$1,2-2,6$ & 5 & 9.3 & 2 & 5 & 9.3 & 2 & Rendah \\
$2,7-4,4$ & 8 & 15 & 4 & 7 & 13 & 4 & Sedang \\
$4,5-6,5$ & 7 & 13 & 5.5 & 3 & 5.6 & 6 & Tinggi \\
$>6,6$ & 1 & 1.9 & 8 & 7 & 13 & 8.1 & Sangat tinggi \\
\hline
\end{tabular}

Dari tabel distribusi indeks DMF-T dan status karies berdasarkan jenis kelamin yang ditentukan dengan menggunakan kategori dalam perhitungan indeks DMF-T menurut WHO, nilai DMF-T yang masuk dalam kategori sangat tinggi ditemui pada 1 anak laki-laki dan 7 anak perempuan dengan nilai DMF-T >6,6. Jika dilihat dari banyaknya anak untuk masingmasing kategori DMF-T, ada dua kategori pada anak laki-laki dan dua kategori pada anak perempuan dengan nilai presentase dari jumlah anak yang paling banyak, yaitu dengan kategori status karies sangat rendah sejumlah 9 anak lakilaki dan status karies sedang sejumlah 8 anak laki-laki serta 7 anak perempuan dalam kategori status karies sedang dan 7 anak perempuan dalam kategori status karies sangat tinggi (Tabel 1).

\section{BAHASAN}

Dari hasil penelitian terhadap 54 anak dari keluarga pemegang Jamkesmas di kelurahan Tumatangtang 1 kecamatan Tomohon Selatan didapati sebanyak 24 anak berjenis kelamin perempuan dan 30 anak berjenis kelamin lakilaki. Dari 54 anak, 21 anak berusia 11 tahun dan 33 anak berusia 12 tahun. Subjek penelitian adalah anak usia 11 - 12 tahun, karena menurut data dari Departemen Kesehatan Republik Indonesia (Depkes RI) tahun 2009, sebanyak 89\% anak Indonesia di bawah 12 tahun menderita karies gigi. ${ }^{2,3}$ Menurut WHO, usia 12 tahun adalah usia yang penting karena pada usia ini anak lebih muda diajak berkomunikasi dan diperkirakan semua gigi permanen telah erupsi kecuali gigi molar tiga, serta usia tersebut merupakan kelompok yang mudah dijangkau oleh usaha kesehatan gigi sekolah. Oleh karena itu, usia 12 tahun ditetapkan sebagai usia pemantauan global untuk karies. ${ }^{8,9}$

Dari hasil pemeriksaan DMF-T pada 54 anak ini, didapati total indeks D (Decay) berjumlah 159, M (Missing) berjumlah 45, dan F (Filling) tidak ada (Gambar 1). Jika data dibagi berdasarkan jenis kelamin, 30 anak laki-laki memiliki indeks D (Decay) berjumlah 70, M (Missing) berjumlah 21 dan F (Filling) tidak ada. Sedangkan pada 24 anak perempuan memiliki indeks D (Decay) berjumlah 89, M (Missing) berjumlah 24 dan F (Filling) tidak ada.

Dari hasil tanya jawab langsung dengan responden, kebanyakan masyarakat di Kelurahan Tumatangtang 1 sering mengonsumsi air minum yang bersumber dari air sumur. Kadar fluor dalam air yang berasal dari danau, sungai atau sumur buatan yang ada di daerah pegunungan adalah di bawah $0,5 \mathrm{mg} /$ liter yaitu lebih rendah dari nilai yang direkomendasikan $1 \mathrm{mg} / \mathrm{liter}$ atau $1 \mathrm{ppm}$. Konsentrasi fluor $1 \mathrm{ppm}$ pada air minum berdasarkan studi epidemiologi di berbagai negara mempunyai efek fluorosis sangat ringan, tidak memengaruhi estetik dan efisien dalam upaya pencegahan karies. Dari pertimbangan 
manfaat dan kerugiannya WHO merekomendasikan tingkat $1 \mathrm{mg} /$ liter fluor dalam air minum untuk mencegah karies gigi. ${ }^{10}$ Berdasarkan hal ini, penulis berpendapat bahwa status karies dengan indeks rata-rata DMF-T 3,8 dari 54 anak usia 11-12 tahun di kelurahan Tumatangtang 1 kecamatan Tomohon Selatan yang dikategorikan sedang, dapat dipengaruhi oleh letak geografis dari daerah pegunungan kelurahan Tumatangtang 1 tersebut.

Dari pengukuran berdasarkan jenis kelamin, 30 anak laki-laki usia 11 - 12 di Kelurahan Tumatangtang 1 memiliki rata-rata indeks DMF$\mathrm{T}$ sebesar 3. Nilai ini lebih rendah jika dibandingkan dengan rata-rata indeks DMF-T dari 24 anak perempuan yang nilainya sebesar 4,7 (Gambar 2). Selama masa kanak-kanak dan remaja, perempuan menunjukkan nilai indeks karies lebih tinggi dari laki-laki. ${ }^{11}$ Hasil penelitian dari Sihombing, tentang karakteristik penderita karies gigi di RSU Dr. Pirngadi di Medan, menunjukkan bahwa pengalaman karies lebih tinggi pada wanita daripada pria selama periode anak-anak sampai remaja. ${ }^{12}$

Usia 11-12 tahun merupakan masa peralihan dari kanak-kanak menjadi remaja yang mengakibatkan peningkatan karies pada anak perempuan karena dipengaruhi oleh erupsi gigi yang cepat serta perubahan hormonal.,13 Umumnya waktu erupsi gigi anak perempuan dapat lebih cepat 1 hingga 6 bulan dibandingkan anak laki-laki karena disebabkan oleh faktor hormonal yakni pengaruh hormon estrogen. Hormon tersebut berperan dalam pertumbuhan dan perkembangan sewaktu anak perempuan mencapai pubertas.Erupsi gigi yang lebih cepat mungkin mengakibatkan gigi lebih lama terpapar oleh makanan kariogenik.Selain itu, komposisi saliva pada masa pubertas dan menstruasi juga dapat mengalami perubahan. Faktor-faktor inilah yang mungkin merupakan salah satu alasan kecenderungan peningkatan karies pada anak perempuan. ${ }^{14}$

Berdasarkan kategori status karies dalam perhitungan DMF-T responden menurut kriteria WHO, sejumlah 11 anak (20\%) termasuk dalam kategori sangat rendah, 10 anak (19\%) dalam kategori rendah, 15 anak (28\%) dalam kategori sedang, 10 anak (19\%) dalam kategori tinggi dan 8 anak (15\%) masuk dalam kategori sangat tinggi, sehingga prevalensi karies yang paling banyak terdapat dalam kategori sedang.

Dari tabel distribusi indeks DMF-T berdasarkan kategori dalam perhitungan indeks DMF-T menurut WHO, nilai DMF-T yang masuk dalam kategori sangat tinggi ditemui pada 1 anak laki-laki dan 7 anak perempuan dengan nilai DMF-T >6,6 (Tabel 1). Tingginya indeks DMF-T ini dapat disebabkan oleh kurangnya pengetahuan dan kesadaran merawat gigi dan mulut serta faktor sosial ekonomi di Kelurahan Tumatangtang 1 Kecamatan Tomohon Selatan. Kondisi sosial ekonomi keluarga didasarkan pada pendapatan, tingkat pendidikan orang tua, pendapatan orang tua dan status sosial di dalam masyarakat seperti hubungan dengan masyarakat, asosiasi dalam kelompok masyarakat, dan persepsi masyarakat atas keluarga. ${ }^{15}$ Status sosial ekonomi orang tua sangat berpengaruh bagi pemenuhan kebutuhan hidup sehari-hari termasuk pemenuhan kebutuhan perawatan medis dan untuk memenuhi kebutuhan perawatan ini, perlu adanya pendapatan yang cukup dalam sebuah keluarga.

Dari hasil survei secara keseluruhan, tingkat sosial ekonomi dari orang tua responden bisa dikategorikan berada pada tingkat sosial ekonomi rendah. Karena itu, responden mendapat kartu Jamkesmas dengan harapan masyarakat miskin dan tidak mampu dapat memanfaatkan kartu ini untuk memperoleh pelayanan kesehatan yang layak. ${ }^{6,7}$ Tapi pada kenyataannya, puskesmas di Kelurahan Tumatangtang 1 tidak difasilitasi dengan poli gigi sehingga keluarga pemegang kartu Jamkesmas tidak bisa mendapatkan pelayanan gigi dan mulut. Ini bisa terlihat dari tidak adanya nilai $\mathrm{F}$ (Filling) dalam indeks DMF-T pada 54 anak di Kelurahan Tumatangtang 1 Kecamatan Tomohon Selatan (Gambar 1). Keluarga pemegang kartu Jamkesmas bisa saja mendapatkan perawatan gigi dan mulut, jika disertai dengan sistem rujukan dari puskesmas ke pelayanan tingkat lanjut seperti Balkesmas (Balai kesehatan masyarakat), rumah sakit pemerintah termasuk rumah sakit khusus, rumah sakit TNI/Polri dan rumah sakit swasta yang tujuan rujukannya ditentukan oleh pihak puskesmas setempat. ${ }^{16,17}$ 


\section{SIMPULAN}

Status karies anak umur 11-12 tahun pada keluarga pemegang Jamkesmas di Kelurahan Tumatangtang 1 Kecamatan Tomohon Selatan berada pada kategori status karies sedang yang berdasarkan indeks DMF-T rata-rata sebesar 3,8.

\section{SARAN}

Diharapkan penyuluhan tentang kesehatan gigi dan mulut lebih ditingkatkan lagi dan adanya sistem rujukan dari puskesmas yang tidak difasilitasi dengan poli gigi yang ada di Kota Tomohon.
Bagi pemerintah diharapkan untuk dapat meningkatkan pelayanan kesehatan gigi dan mulut disetiap puskesmas yang ada di kota Tomohon khususnya pelayanan bagi anggota keluarga pemegang kartu Jamkesmas

Bagi orang tua diharapkan dapat memberikan contoh perilaku dan pendidikan tentang pemeliharaan kebersihan gigi dan mulut yang benar, sehingga dapat memberikan dampak positif bagi anak dalam menjaga dan memelihara kebersihan gigi dan mulut secara mandiri.

\section{DAFTAR PUSTAKA}

1. Sondang P, Hamada T. Menuju gigi dan mulut sehat. Medan: USU Press; 2008. h.4-15,4-24

2. Hermawati G, Hidayanti L, Korneliani K. Dampak konsumsi makanan kariogenik terhadap keparahan karies gigi pada anak pra sekolah. [serialonline] 2009 [cited April 2013]. Available from URL: http://journal.unsil.ac.id/

3. Kartika PS. Efektivitas komik dental sebagai upaya peningkatan pengetahuan tentang pencegahan karies gigi pada anak usia sekolah dasar. [serial online] 2012 [cited April 2013]. Available from URL: http://webcache.googleusercontent.com/search?q=cache:xMXmMjmiE60J:210.57.222.58/go.php\%3Fid\% 3Dgdlhub-gdl-s1-2012

4. Happy R. Angka kemiskinan. [serial online] 2013 [cited Desember 2013]. Available from URL: http://m.antaranews.com/berita/390875/angka-kemiskinan-2013-tercatat-1137-persen

5. BPS provinsi Sulawesi Utara. [serial online]2013 [cited Desember 2013]. Available from URL: http://sulut.bps.go.id/download.php?fileName=KEMISKINAN_MAR_13.pdf

6. Jamsos Indonesia. Regulasi Jamkesmas. [serial online] 2013 [cited Desember 2013]. Available from URL: http://www.jamsosindonesia.com/prasjsn/jamkesmas/regulasi

7. Program jaminan kesehatan masyarakat (JAMKESMAS). [serial online] 2013 [cited Desember 2013]. Available from URL: http://tnp2k.go.id/tanya-jawab/klaster-i/program-jaminan-kesehatan-masyarakatjamkesmas/

8. Haryani W. Hubungan antara konsumsi karbohidrat dengan tingkat keparahan karies gigi pada anak usia prasekolah di Kecamatan Depok, Sleman Daerah Istimewa Yogyakarta. [serial online] 2003 [cited April 2013]. Available from URL:http://etd.ugm.ac.id/index.php?mod=penelitian_detail\&sub=PenelitianDetail\&act=view\&typ=html \&buku_id=19632\&obyek_id=4

9. Warni L. Hubungan perilaku murid SD kelas V dan VI pada kesehatan gigi dan mulut terhadap status karies gigi di wilayah Kecamatan Delitua Kabupaten Deli Serdang tahun 2009. [seial online] 2009 [cited April 2013]. Available from URL: http://repository.usu.ac.id/bitsream/123456789/7903/1/10E00470.pdf

10. Agtini M D, Sintawati, Tjahja I. Fluor dan kesehatan gigi. [serialonline] 2005 [cited Desember 2013]. Available from URL: http://jdr.sagepub.com/content/87/4/340

11. Berwulo H. Gambaran tingkat karies berdasarkan status kebersihan gigi dan mulut pada siswa sekolah dasar di Desa Ranowangko II Kecamatan Kombi [Skripsi]. Manado: Universitas Sam Ratulangi, 2009.

12. Sihombing J. Karakteristik penderita karies yang berobat di RSU Dr. Pirngadi Medan [Skripsi]. Medan: Universitas Sumatra Utara, 2009.

13. Hidayati L. Hubungan karakteristik keluarga dan kebiasaan konsumsi makanan kariogenik dengan keparahan karies gigi anak sekolah dasa [Skripsi]. Semarang: Universitas Diponegoro, 2005.

14. Sihombing J. Karakteristik penderita karies yang berobat di RSU Dr. Pirngadi Medan [Skripsi]. Medan: Universitas Sumatra Utara, 2009. 
15. Demarest EJ, Reisner ER, Anderson LM, Humphrey DC, Farquhar E, Stein SE. 1993. Review of research on achieving the nation's readiness goal. Washington, DC: U.S. Department of Education

16. Hobdell MH, Oliveira ER, Bautista R, Myburgh NG, Lalloo R, Narendran S, et al. Oral diseases and socio-economic status (SES). British Dent J; 2003. 194(2): 91-6

17. Departemen Kesehatan RI. Pedoman pelaksanaan Jaminan Kesehatan Masyarakat. [serial online] 2008 [cited Desember 2013]. Available from URL: http://hukum.unsrat.ac.id/men/menkes2008_125_lamp.pdf 